\title{
"Everyone Dreamt of Eating Plenty of Bread...": Provision with Goods of First Priority and Measures of Social Assistance to Students in Soviet Province from 1941 to 1945
}

\author{
Natalia V. Pashina ${ }^{1}$ \\ Tatyana A. Kattsina ${ }^{2}$ \\ Ludmila E. Marinenko ${ }^{3}$ \\ Svetlana A. Lisina ${ }^{4}$ \\ 1, 2, 3 Federal State Autonomous Educational Institution of Higher Education "Siberian Federal University" \\ Svobodny av., 79, Krasnoyarsk, 660041, Russia \\ ${ }^{4}$ Krasnoyarsk Institute of Economics of Saint Petersburg University of Management and Economics Russia \\ Academician Kirensky str,, 70A, Krasnoyarsk, 660100, Russia
}

\section{Doi:10.5901/mjss.2015.v6n6s1p77}

\section{Abstract}

\begin{abstract}
The article describes provision with food and goods of first priority for students of higher and vocational secondary education institutions during the Great Patriotic War of 1941-1945. This issue was not covered well enough in scientific literature. In their studies of the problem the authors use published and archive resources about Krasnoyarsk, administrative centre of Krasnoyarsk Region. During the Great Patriotic War Krasnoyarsk Region was one of the areas for relocation of evacuee institutions and facilities together with a large number of people from western areas. Krasnoyarsk Region attracted with its vast territory (2.34 million square kilometers), detachment from the central part of the country and from the battle ground. It was sparsely populated with severe climate and it did not have well-developed transportation system or social infrastructure. The work reveals the idea that in the wartime measures of students' social assistance were very limited, many everyday difficulties were not overcome. Nevertheless, we came to a conclusion that state support of education sphere in the wartime prevented sudden reduction of the quantity of educational institutions and their contingent. In those complicated conditions Soviet education system continued providing for the needs of economics with qualified specialists. The materials of the study specify the scientific idea of living conditions of the population and its social assistance measures in the wartime, create additional opportunities for comparative study of the issue in other regions and sociodemographic population groups.
\end{abstract}

Keywords: higher education, state labour reserves, the Great Patriotic War, Krasnoyarsk, restricted supply, restricted provision.

\section{Introduction}

The acute character of the topic is determined by the $70^{\text {th }}$ anniversary of the victory in the Great Patriotic War as well as by the Russian reforms of social sphere and discussions about them. By the beginning of the 1940s Soviet higher school became rather a strong and efficient system of staff training for the national economy. Joining the massive armed conflict in June 1941, Soviet state faced the necessity not only to mobilize resources and population for struggle with the military adversary, but also to work out a system of measures to mitigate the effects of the increased social mobility.

The modern period of the Russian historiography of the Great Patriotic War pays attention to problems that were out of the research interest before. They include historical questions of the population's everyday life in the wartime. The working ability level of people, moral and psychological state of the society depend on the very condition of housing issue, public health, system of provision with essentials. As exemplified by Krasnoyarsk Region this issue is studied by A. V. Shalak (1998; 2000), L. E. Mezit (2010), K. A. Shalatova (2012) and others. However social policy of the state regarding the school youth in the wartime was not separately studied. Meanwhile young people are a special sociodemographic group that is characterized by a high mobility level and labout potential. Various social factors influence their education in both macro- and microlevel.

The study aims at the review of the provision with goods of first priority, analysis of social assistance measures to the students of higher and vocational secondary education during the Great Patriotic War (1941-1945) on the example of Krasnoyarsk Region. 


\section{Material of the Study}

The article was written with the involvement of new documents from the archives of Krasnoyarsk Region.

The following documents served as sources for the study: legislative and statutory enactments from the area of social assistance legal regulation in the years of the Great Patriotic War; documents of management and record keeping (organizational/management papers, inventory and control papers, accounting and information papers) and sources of personal character (letters and complaints of the students to executive offices on the issues of allowance assignment and payment) from Fund $\Pi-26$ (Krasnoyarsk Regional Committee of Communist Party of the Russian Soviet Federative Socialist Republic), Fund P-1386 (Krasnoyarsk Regional Congress of People's Deputies and its executive committee) and Fund P-1478 (General Directorate of Economics and Industry Development of Krasnoyarsk Region Administration) of State Archive of Krasnoyarsk Region, Fund 513 (Achinsk municipal bureau of ration cards) of Achinsk city records.

\section{Results}

\subsection{Hardships of the wartime and higher school in Krasnoyarsk}

As the Great Patriotic War began, Krasnoyarsk Region became one of the areas where they relocated a large number of people from the western areas together with evacuee factories and institutions. By the year of 1942 there arrived more than 75 thousand people, equipment from about 50 large factories and plants (Kattsina et al., 2013), Voronezh Dental Institute and two medical higher educational institutions from Leningrad in the region. Notwithstanding mass mobilizations and voluntary going to war, Krasnoyarsk population increased by half. The city turned into a big industrial centre. Industrial output increased 7-8 times during the war (State Archive of Krasnoyarsk Region, Fund P-1478, Series 3, File 49, Folio 1).

At the same time, evacuation deteriorated material and technical resources of higher educational institutions, because part of the rooms of the institutes was given to defence enterprises and hospitals. Thus, Siberian Forest Engineering Institute in Krasnoyarsk preserved only $14 \%$ of its pre-war educational facilities. Variable maintenance costs of higher school were also cut down in the federal budget. Under such conditions decisions to unite one-field educational institutions, both local and those evacuee to the region from the country centre became quite common. For instance, on the basis of three evacuee medical institutions they formed Krasnoyarsk Medical Institute. Evacuation helped to preserve pre-war academic staffs and student collectives, as well as partial material resources of the institutions (training equipment, academic libraries). The process of higher educational institutions reevacuation to the west that began in the middle of 1942 resulted in drastic reduction of the number of teachers and decrease of the academic staff qualification level. Newly formed educational institutions that just realized the admission got into a particularly complicated situation. To prevent Krasnoyarsk Medical Institute from closing they postponed the comeback of teachers to their former places of residence till the end of the war (Vodichev et al., 2010).

During the Great Patriotic War there were four higher educational institutions in action in Krasnoyarsk Region (Forest Engineering Institute, Pedagogical Institute, Teacher's Institute, and Medical Institute). In 1941 they suffered the reduction of the number of applicants (and in general around the country the reduction summed up to $41.4 \%$ ). The educational institutions managed to solve the complicated task of substitution of the requisitioned male students by means of the increasing girls' admittance. For instance, in 1940-1941 school year female students contingent constituted $58 \%$, in 1942-1943 school years it became 77\% (Sivertseva, 1995).

To accelerate specialists training the training time was reduced. Thus, till 1943 Forest Engineering Institute realized triennial education. Hungry students worked in cold unequipped classes, often deprived of electricity, necessary instruments or chemical agents. Notwithstanding the hard working conditions, higher educational institutions of the city got comparatively high learning achievements. Excellent and good marks amounted to almost $67 \%$ in the wartime in Forest Engineering Institute (Fiodorova et al, 2014).

As the war began, provision of population with food and goods of first priority drastically worsened. Planned management allowed the state creating a system of centralized distribution of the most important food products and articles of consumption. Transition to the ration card system in the country lasted from July till November 1941. Bread tickets were introduced in Krasnoyarsk on September 1, 1941. Supply rate was determined according to commodity reserves and varied according to 4 population groups: production workers, non-manual workers, dependants and children below 12 years of age (Pogrebniak, 2000; Mezit, 2010). In this hierarchy consumption system students of higher and vocational secondary education referred to the dependants group. In 1941-1943 daily bread supply for this group was limited to $400 \mathrm{~g}$ (Zhitkov et al., 2015). 
Distribution of bread tickets among population was performed monthly, and dispatch of bread according to the bread tickets was done in exchange to correspondent coupons within the stipulated limit every day. It was allowed to dispatch bread for the next day. Expired bread coupons were cancelled. In connection with the people's going to eatinghouses divided coupons were introduced into bread tickets, as well as into cards for meat, fish, fats and cereal. Thus, the daily card for $400 \mathrm{~g}$ of bread included two coupons for $300 \mathrm{~g}$ and $100 \mathrm{~g}$ (Zhitkov et al., 2015).

Step by step restricted supply of population with non-foods was also introduced. Sale of restricted non-foods was performed within the limits stipulated for each population category as a particular number of equivalent units (coupons) for each type of goods. In accordance with the general limit and number of coupons reckoned for each good the owner of such card had the right to buy at his own choice during its validity period any restricted goods that were available. Thus, cards for non-foods for students included 80 coupons. While purchasing a pair of shoes for adults a person had to give back 50 coupons, for a coat -80 coupons, for a woman wool or silk dress -60 coupons, for a cotton dress -40 coupons, for a piece of laundry soap - 2 coupons, etc (State Archive of Krasnoyarsk Region, Fund P-1386, Series 1, File 840, Folios 34 and 34 verso; Zhitkov et al., 2015).

Every month academic boards compiled lists of expectants for bread tickets and ration cards and sent them to the correspondent card bureau, and after the cards were handed to students, the boards inserted into them the student's surname, name and patronymic and certified them by the seal of the educational institution. Thus, in August 1943 bread tickets were handed to 4993 students of Krasnoyarsk higher education institutions (State Archive of Krasnoyarsk Region, Fund П-26, Series 13, File 456, Folio 149).

Limitation of the centralized funds and short supplies to them (for about $1 / 3-1 / 4$ ) induced the regional government to support the population occasionally by means of local reserves. For instance, on February 4, 1943, one-time ration was given to 500 students and teachers (that is $60.9 \%$ of the total quantity of those under provision) of Krasnoyarsk Medical Institute. Regional reserve handed them $500 \mathrm{~kg}$ of sugar and confectionery, $250 \mathrm{~kg}$ of butter, $500 \mathrm{~kg}$ of cereal (State Archive of Krasnoyarsk Region, Fund $\Pi-26$, Series 13, File 456, Folio 79) which meant $1 \mathrm{~kg}$ of sugar and confectionery, $0.5 \mathrm{~kg}$ of butter and $1 \mathrm{~kg}$ of cereal per person.

The war gave rise to public catering in Krasnoyarsk. This way was easier for the country to provide for the separated supply to the population, to make efficient use of the funds meant for this purpose. Work of social targeted eating-houses was a peculiarity, because ration sets for different population categories differed considerably in their volume, quality and calorific value. For instance, teaches got the provision as non-manual workers, but candidates of sciences - as governing establishment. According to the limits stipulated in February 1942 this category of scientific workers were to receive monthly $500 \mathrm{~g}$ of cocoa or coffee and $300 \mathrm{~g}$ of chocolate (State Archive of Krasnoyarsk Region, Fund $7-26$, Series 4, File 55, Folio 14).

Students' menu card included dishes with low calorific value. "In winter eating-houses cooked "shchi" of hot water and coarsely chopped frozen cabbage with a few drops of vegetable oil. The main course was almost always herrings (a piece) with a spoon of some garnish, the third course was sugarless tea, but sometimes they offered stewed fruit or jellydrink". Students gave these dishes jokey nicknames: "blue night" (soup of beetroot top), "autumn" (water with peas), "brown eyes" (soup of roach heads). As the wartime students recollect, "by the middle of lectures (they started at 9 am) we were already hungry. Hunger was exhausting" (Bukin, 1992). Eating-houses lacked tableware (spoons, plates, glasses), this increased queuing time. For a plate of soup and a glass of sugarless tea a coupon for cereal, sugar and fat was cut off the ration card. "We spent all the cards, except the bread tickets, within 10 days or two weeks at best. The remaining time we spent half-starved. Everyone dreamt of eating plenty of bread!" students wrote (Moskvitina, 2013).

The so called additional high diet ("AHD") was assigned to successful students who especially needed high calorie diet. Among students this abbreviation stood for "adjourned hour of death". AHD cards were given to the students by the labour union organization and could be used for having a meal in a special eating-house. A dinner cost coupons for $200 \mathrm{~g}$ cereal or bread.

Although it was practically never a problem to get food for ration cards, they could not satisfy the needs of the population in nourishment to full extent. People had to compensate for a lack of restricted supply at a collective farm market. And while the country managed to keep the price of food by ration cards almost on the same level during the wartime, market prices grew very fast. Thus, in the summer of 1941 one kilogram of potatoes cost 1-2 rubles at Krasnoyarsk collective farm market, but already in the winter of 1942 it already cost 15 rubles per kilogram (State Archive of Krasnoyarsk Region, Fund $\Pi$-26, Series 3 File 429, Folios 77-79).

In 1943 after cultivated areas of the country suffered a severe drought the government took extra measures for conserving rations. Bread rates were decreased in the autumn of 1943 for all population categories on the restricted food provision. Starting from November 21, 1943, dependants and children started receiving $300 \mathrm{~g}$ of bread (Zhitkov et al., 2015). 
With the idea of manufacturing pragmatism and interest in formation of professional beau monde the government tried to protect students from hunger and stimulate their studies. On the background of food situation deterioration in the country the Decree of the Council of People's Commissars (CPC) of the Union of Soviet Socialist Republics (the USSR) dated February 10, 1943, "On the improvement of students' nourishment in higher educational institutions" assumed great significance. It stipulated the students supply with food products according to the rates of the workers of industry, transport and communication. They created a special department of living support to students of higher educational institutions as part of All-Russian Committee on the Issues of Higher School affiliated with CPC (Kruglianskiy, 1970; Gizhov, 2014).

CPC Decree No. 996 "On the amounts and order of allowance appointment in higher educational institutions and technical schools and on the exemption of students from the draft to the Red Army" came into force on September 15, 1943 (Corpus of decrees and orders of the USSR Government, 1943). Even before the war began higher education in the country was announced to be fee-paid. On October 2, 1940, CPC of the USSR issued Decree No. 1860 "On the imposition of charges for studying in the upper school and in higher educational institutions of the USSR and on the change of the allowance appointment order". Education fee in higher educational institutions in Moscow, Leningrad and capitals of the union republics was 400 rubles, in other cities -300 rubles, in art, theater and musical higher educational institutions -500 rubles (Corpus of decrees and orders of the USSR Government, 1940).

The decree of CPC of the USSR dated September 15, 1943, appointed additional financial resources for allowance appointment to all the successful students of higher educational institutions, whereas before that moment only those who got good and excellent grades could receive the allowance. Higher school and technical school students who had excellent marks in all the subjects received $25 \%$ increased allowance. In the end of the war by the order of the government centralized provision was also extended to students of career enhancement short-term classes. These students in Krasnoyarsk higher educational institutions received food products for the schooling period according to the rate of the workers of industry, transport and communication and bread rate of $500 \mathrm{~g}$ (Achinsk State Archive, Fund 513, Series 1, File 3, Folio 27).

Allowance amounts differed considerably depending on student's belonging to this or that educational institution and on the academic course (Table 1, compiled on the materials of Corpus of decrees and orders of the USSR Government, 1943).

Table 1: Allowance amount for the students of higher educational institutions and technical schools in 1943-1945 (rubles)

\begin{tabular}{|c|c|c|c|c|}
\hline \multirow[b]{2}{*}{ 岕 } & \multicolumn{2}{|c|}{ Higher educational institutions } & \multicolumn{2}{|c|}{ Technical schools } \\
\hline & $\begin{array}{l}\text { Most important } \\
\text { industrial and transport }\end{array}$ & $\begin{array}{l}\text { Industrial, transport, agricultural, } \\
\text { pedagogical, medical and others }\end{array}$ & $\begin{array}{l}\text { Most important } \\
\text { industrial and transport }\end{array}$ & $\begin{array}{l}\text { Industrial, transport, } \\
\text { agricultural, pedagogical, } \\
\text { medical and others }\end{array}$ \\
\hline 1 & 210 & 140 & 125 & 80 \\
\hline 2 & 240 & 160 & 150 & 100 \\
\hline 3 & 275 & 185 & 175 & 120 \\
\hline 4 & 275 & 185 & 200 & 140 \\
\hline 5 & 315 & 210 & - & - \\
\hline
\end{tabular}

Taking care of the students' well-being, the government solved an important task on the attraction of young specialists to the most important sectors of national economy. The aims of enhancement and growth of the defence economics, reconstruction and development of national economy in the vacate areas required preparation of highly skilled professionals with higher education. Notwithstanding the hard conditions of the wartime, Krasnoyarsk higher educational institutions gained comparatively high learning achievements. At the same time, real life level of this or that population group in the wartime was regulated not so much by the amount of government monetary allowances, as by card provision rates and quality of goods supply to the funds. Nevertheless, population provision in Krasnoyarsk in the wartime was characterized by a number of shortcomings, such as: long-time delays of food giving in the shops, some products were not handed out for months and the debt was not covered (it was cancelled), every month eating-houses did not hand out goods to full extent either and they did not always cover the debts. Supply with manufactured goods was organized even worse: "overcoats or wool cloth, linen, men shoes are not handed out, women shoes are poorly given..." (State Archive of Krasnoyarsk Region, Fund $\Pi-26$, Series 14, File 71, Folios 5 a and 5 a verso). 


\subsection{Hardships of the wartime and students of state manpower reserves}

Sudden aggravation of industrial staff lack in the first year of the war made the problem of economic mobilization of human potential in the cities of back areas of the USSR rather acute. The utterly centralized system of state manpower reserves represented one of the basic mechanisms of the directed distribution of the manpower in favour of the leading branches of national economy. It gained a particular significance in the eastern regions of the country, where after the first stage of industrial evacuation finished (July - December 1941) a large part of the military and industrial potential of the country was concentrated (Romanov, 2011).

Building a system of state manpower reserves upon the initiative of state government bodies happened several months before the beginning of the Great Patriotic War. By the Decree of the Presidium of Supreme Council of the USSR "On state manpower reserves of the USSR" dated October 2, 1940, vocational and railway schools with a two-year curriculum and schools of factory trade apprenticeship with a six-month curriculum were opened (Decrees of the Party and government on economic issues..., 1967). General Directorate of State Manpower Reserves as part of CPC of the USSR (the Council of People's Commissars) administered these educational institutions on a national scale. In Krasnoyarsk Region this administration was performed by Regional Directorate of Manpower Reserves of Executive Committee of the Local Council of People's Deputies.

Just before the Great Patriotic War began there functioned 7 schools of factory trade apprenticeship, 4 vocational schools and 2 railway schools in Krasnoyarsk Region, where about 2.5 thousand people mastered the profession. A large part of these students consisted of teenagers under 18 - migrants from rural areas.

Krasnoyarsk Region accepted the evacuee staff from 6 vocational and railway schools and schools of factory trade apprenticeship from the towns of Velikie Luki, Kolomna, Efremov, Kaluga, and Aleksin. Organization of vocational schools and schools of factory trade apprenticeship in the wartime was accompanied by the lack of construction materials, training equipment, and tools. Thus, students, foremen and operation personnel of vocational school No. 3 established in 1943 at the premises of thermal power plant took shelter in the slightly heated barracks during the February frosts. The school did not possess its own workshops. Due to the absence of classes the students did not receive theoretical knowledge (Fiodorova et al., 2014).

Public nourishment service to the students of state manpower reserves was performed by departments of working provision of the plants in whose facilities the schools were organized. Students received food within the limits of cards of the workers of the basic plant (Table 2, compiled on the materials of State Archive of Krasnoyarsk Region, Fund $\Pi-26$, Series 15, File 15, Folio 204).

Table 2: Food supply monthly rate of students of state manpower reserves (g/person), according to the government regulatory acts

\begin{tabular}{l|c|c}
\multirow{2}{*}{ Food product } & \multicolumn{2}{|c}{ Regulatory act } \\
\cline { 2 - 3 } & $\begin{array}{c}\text { Order of CPC of the USSR dated September } \\
14,1943, \text { No. 476/1464 }\end{array}$ & $\begin{array}{c}\text { Decree of CPC of the USSR dated September 21, } \\
1945, \quad \text { No. 2412 }\end{array}$ \\
\hline Meat & 2300 & 2300 \\
\hline Cereal, pasta & 1400 & 2500 \\
\hline Fats & 750 & 750 \\
\hline Sugar & 600 & 150 \\
\hline Cheese & 150 & 150 \\
\hline Flour & 300 & 1500 \\
\hline Milk & - & 3000 \\
\hline Tea & 30 & 30 \\
\hline Potatoes & 12000 & 12000 \\
\hline Vegetables & 9000 & 9000 \\
\hline Eggs & $6 \mathrm{pcs}$ & $6 \mathrm{pcs}$ \\
\hline Bread (daily allowance) & 700 & 700
\end{tabular}

The students whose industrial training passed in underground jobs or in hot and detrimental shops received food according to the rates of the workers of the correspondent professions. Those who over fulfilled the production norms took nourishment at the account of limits of the factories that placed these orders.

The date in Table 2 represent that in the wartime the restricted ration of students of elementary and secondary vocational education remained almost unchanged (except 3 items). In general, nourishment of the state manpower 
reserves students was quite meager and was hardly enough to prevent starvation death. However, the teenagers who fell beyond the state restricted provision limits did not receive even this ration. Thus, using limited resources, the state could ensure attraction of young people to manufacture.

As a matter of fact, trade companies of the region and public catering enterprises of the manufacturing plants in whose facilities vocational schools and schools of factory trade apprenticeship were established did not fulfill the statutes on the students' supply from year to year. Internal reports to the office of Regional Directorate of Manpower Reserves reflect the true situation with the students' provision. During almost the whole restricted supply period the ration funds of vocational and railway schools and schools of factory trade apprenticeship were not provided with food to full extent. Thus, Minusinsk vocational school No.5 of Yenisey shipping company counted 223 students. During January and February 1945 the working supply department of Yenisey shipping company administration underdelievered to the school $67 \mathrm{~kg}$ of meat and fish, $452 \mathrm{~kg}$ of cereal and pasta, $36 \mathrm{~kg}$ of fats, $240 \mathrm{~kg}$ of sugar and confectionery, $67 \mathrm{~kg}$ of cheese, $134 \mathrm{~kg}$ of flour for adding to dishes, $14 \mathrm{~kg}$ of tea, $58 \mathrm{~kg}$ of potatoes, $1595 \mathrm{~kg}$ of vegetables and 2676 eggs. It was a widely spread practice to substitute some food products for students of state manpower reserves with those of lower quality. Instead of cereal the students received potatoes, instead of eggs-egg powder, instead of milk - skin milk or thrusting. Meat and fish were handed out in extraordinary circumstances, but more often they were also substituted with potatoes or flour. The quality of food supplied to the school funds was low: rotten tomatoes, frozen cabbage, rank vegetable oil. Sometimes up to $50 \%$ of supplied vegetables were uneatable (State Archive of Krasnoyarsk Region, Fund $\Pi-26$, Series 15, File 15, Folio 204).

Students of schools of factory trade apprenticeship and vocational schools had meals together with other workers in plants canteens and eating-houses. Daily ration menu was very limited. In the morning they offered bread and tea. Unvaried dinner mostly consisted of flower and cereals (cereal soup, porridge, pickle soup). Fresh vegetables were absent as a rule. Instead of them the eating-houses offered pickled tomatoes or green cabbage leaves. In some schools desperate students went on a strike and refused to eat, they called the prepared meals "prison gruel". Low-quality nourishment produced a negative impact on students' labour capacity and health. Such diseases as vitamin deficiency, tuberculosis, and anemia were widely spread among them. The situation with students' nourishment organization was complicated by the fact that students of vocational schools and schools of factory trade apprenticeship were teenagers evacuee from other regions (Smolensk, Leningrad, Kharkov Area) and they could not get support from their parents.

Constant hunger made teenagers steal. The smartest of them forged ration coupons to receive additional meals. Others organized criminal gangs and went on extortion, stealing of ration cards, dug down under the warehouses where food was kept, robbed apartments and vegetable gardens of the local people. Many criminal acts were performed out of despair.

Apart from food products, after graduation each student of vocational technical school was supposed to receive in personal free use the following possessions: short padded overcoat, work overalls, one pair of shoes, 2 pairs of underwear, a headwear, 2 pairs of socks, 3 handkerchiefs and a trouser belt. Most students did not have coats, shoes, and additional underwear, so they had to miss classes. Krasnoyarsk vocational school No. 3 did not hand out authorized equipment and stores at all. Hard working conditions, life disorder, constant feel of hunger resulted in students' escapes from school. Qualitative changes in provision of students of state manpower reserves started happening only in the end of the 1940-s.

\section{Conclusion}

Thus, in the wartime there were considerable household and financial hardships in provision of students of Krasnoyarsk higher educational institutions and state manpower reserves. Most of these hardships were not overcome at all. We cannot but agree to L. E. Mezit's opinion that during the war supply rates were adjusted repeatedly; the adjustments were based on the presence of resources, and the rates were not always increased (Mezit, 2010).

In the conditions of household deformation, family ties breakdowns caused by the war, increase of prices for goods of first priority, insufficient organization of the supply of population the life level of a considerable part of the students of Krasnoyarsk educational institutions became lower and it lead straightly to social strain.

State support of educational sphere in the wartime did not allow a number of educational institutions and their staff to reduce. The network of higher educational institutions and technical schools in Krasnoyarsk Region was not only preserved, but also extended.

With the idea of manufacturing pragmatism and interest in formation of professional beau monde the government strived for protection of students from starvation and motivation of their studies.

The taken measures of students' social assistance contributed to the fact that Soviet education system solved the 
problem of military economics supply with highly qualified personnel and working specialists.

\section{Acknowledgement}

We thank Ministry of Education and Science of the Russian Federation for the financial support of the scientific and research work of public statement of work No. 01201253340 in terms of which the present article was written.

\section{References}

Bukin, S.S. (1992). Monetary income and consumption of the population in Siberia during the Great Patriotic War. Collection of studies "Social sphere of Siberia: tendencies and problems of development" (pp. 73-82) Novosibirsk: Historical Institute of Siberian Department of the Russian Academy of Sciences.

Corpus of decrees and orders of the USSR Government (1940). 27, 910-911. [Electronic resource]. URL: http://istmat.info/node/18852 (July 7, 2015).

Corpus of decrees and orders of the USSR Government (1943). 12, 214-224. [Electronic resource]. URL: http://istmat.info/node/20313 (July 7,2015$)$.

Decrees of the Party and government on economic issues. The years of 1917-1967. Corpus of documents for 50 years period (1967). (Vol. 2. The years of 1929-1940, pp. 774-775). Moscow: Politizdat.

Fiodorova, V.I. (ed.), Mezit, L.E., Gubkin, V.F. et al. (2014). Illustrated history of Krasnoyarsk area (the years of 1917-1991). Krasnoyarsk: RASTR.

Gizhov, V.A. (2014). Educational process in higher schools of Saratov in 1943-1945. Historical, philosophic, political and legal sciences, cultural studies and study of art. Theoretical and practical issues, 9 (47). Vol. 1, 46-48.

Kattsina, T.A., Marinenko, L.E., Alekseev, O.G. and Pogrebniak, A.I. (2013). Professional Commercial Education in Siberia in the XXth Century. Essays on history. Moscow: FLINTA: Nauka.

Kruglianskiy, M.R. (1970). Higher school of the USSR during the Great Patriotic War. Moscow: Higher school.

Mezit, L.E. (2010). Living conditions of Krasnoyarsk Region population during the Great Patriotic War. Herald of Moscow State District University. Series: History and political sciences, 2, 29-32.

Moskvitina, A.S. (2013). Food and financial supply of students of Krasnoyarsk Region in the wartime (1941-1945). Collection of studies of the IXth All-Russian scientific and technical students, graduate assistants and young scientists' conference with international participation, dedicated to the $385^{\text {th }}$ anniversary of Krasnoyarsk City foundation. "Youth and science" [Electronic resource]. URL: http://conf.sfu-kras.ru/sites/mn2013/ (May 7, 2015).

Pogrebniak, A.I. (2000). Problems of provision and commerce in Siberia (1941-1945). The Siberians-Krasnoyarsk citizens in the Great Patriotic War of 1941-1945. Krasnoyarsk: Krasnoyarsk State University.

Romanov, R.E. (2011). Measures of the state government on the attraction of city youth to educational institutions of Novosibirsk state manpower reserves in the first year of the war (on the example of draft campaign of January and February 1942). Issues of state governance and local governance history in Siberia in the end of the XVIth - the beginning of the XXIth century. Digest of the VIlth All-Russian scientific conference (pp. 205-210). Novosibirsk: Nonparel.

Shalak, A.V. (1998). Living conditions and life mode in East Siberia during the Great Patriotic War (1941-1945). Irkutsk: Irkutsk State Economic Academy.

Shalak, A.V. (2000). Social problems of the population of East Siberia (1940-1950). Irkutsk: Irkutsk State Economic Academy.

Shalatova, K.A. (2012). Social and living provision of evacuee military families in Krasnoyarsk Region during the Great Patriotic War. Contemporary issues of historical studies: young scientists' opinion: Digest of the Second All-Russian Youth Scientific Conference (pp. 244-250). Novosibirsk: Historical Institute of Siberian Department of the Russian Academy of Sciences.

Sivertseva, N.L. (1995). The Great Patriotic War and higher school. Sociological studies, 5, 35-44.

Vodichev, E.G., Korobkova, I.P. and Liteynov, A.V. (2010). Higher school in the east part of Russia. Historical encyclopedia of Siberia (Vol. 1, pp. 355-362). Novosibirsk: "Historical heritage of Siberia" publishing house.

Zhitkov, V.B., Voronina, I.V. and Selezniova, E.A. (2015). The Great Patriotic War. Anniversary statistics digest. Moscow: informational and publishing centre "Statistics of Russia". 